на микроциркулацията [18]. Въпреки че може да се извършва на всяко от анатомичните места, в които крайните капиляри заемат ориентация успоредно на кожата (очна конюнктива, периареоларна област и лабиална лигавица), капилярите на нокътната ґънка на ръцете са тези, които поради своята достъпност, са рутинно изследвани (поради тази причина техниката се нарича капиляроскопия на нокътната ґънка) $[18,19]$.

Капиляросокпията трябва да се извършва в помещение с нормална стайна температура между $20-22^{\circ}$ C. Пациентът трябва да е в покой най-малко 15 минути, без да е изложен на екстремни температури, за да се избегне вазоспазъм вследствие на студ, При липса на престой на стайна температура е възможно да се установят данни за спастични капиляри и забавен кръвоток. Трябва да се избягват процедури като маникюр между 15 и 30 дни преди извършването на изследването, тъй като кутикуларната травма може и да променя кръвоизливи, както и да травматизира и да промени нормалното разположение на капилярите [20, 21].

Най-важните индикации за извършване на капиляроскопия включват диференциална диагноза на първичен и вторичен феномен на Рейно, както и оценка на промените в микроциркулацията по типа на склеродермия. При системна склероза капилярните аномалии се появяват и се развиват в ясно определена последователност, наречена склеродер- мен тип, който корелира с наличието на промени и от вътрешните органи $[22,23]$. Капиляроскопските промени са един от класификационните критериите за системната склероза, признат от Европейската лига срещу ревматизма (EULAR) [24].

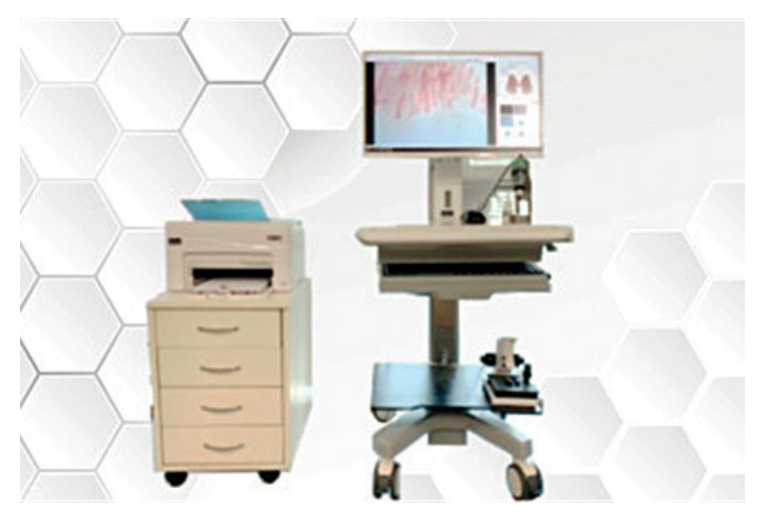

Фиг. 8. Видеокапиляроскопия

Към настоящия момент са описани множество неинвазивни и минимално инвазивни методики за оценка на микроциркулацията, които през годините са имали различен принос в диагностичния процес [25, 26, 27]. С развитието на технологиите на преден план се оказаха методики като лазер-доплер фрлоуметрията (и нейните модернизирани вариации), както и капиляроскопията и видеокапиляроскопията. Те намериха място както в ежедневната практика, така и в множество клинични проучвания.

\title{
METHODS FOR ASSESSMENT OF MICROCIRCULATION
}

\author{
VI. Boyadzhieva, N. Stoilov
}

Clinic of Rheumatology, UMHAT Sv. Ivan Rilski, Medical University - Sofia

\begin{abstract}
To date, many methods have entered rheumatological practice in order to evaluate more accurately the microcirculation. Most of them are non-invasive or minimally invasive, easily accessible, providing different information depending on the specifics of the study. Over the years, some of them (such as chromametry and volumetry) have lost their routine application and have acquired rather historical significance, while others have become an integral part of the rheumatological armentarium. An example of this is video capillaroscopy, which, through its dynamic development over the last 20 years, has evolved in the knowledge of changes in microcirculation in systemic sclerosis, as well as in other systemic connective tissue diseases. The expansion of knowledge in this area has led to the updating of the classification criteria for systemic sclerosis, allowing the addition of capillaroscopic changes as recognized by the European League against Rheumatism (EULAR). Another important indication for performing video capillaroscopy is the differentiation of primary from secondary Raynaud's phenomenon. Laser Doppler perfusion imaging is also used to detect secondary Raynaud's phenomenon in order to distinguish whether reduced blood flow is due to systemic autoimmune disease. Thermography also has a helpful role in diagnosing Raynaud's phenomenon, but unlike the other two methods, it has a much more limited application due to the lack of discriminative ability to distinguish nutritional
\end{abstract}


from thermoregulatory blood flow, which leads to erroneous conclusions in pathological conditions. Venous occlusive plethysmography is one of the „gold standards“ in the assessment of vascular function in health and disease and is an accurate, reproducible and convenient method to assess the effect of new vasoactive drugs. However, its application in everyday rheumatological practice is quite limited.

Key words: methods, microcirculation

Microangiopathy affects the morphology and function of cutaneous microcirculation [1]. Over the years, many non-invasive techniques have perfected knowledge in this area, undergoing a dynamic development - from the oldest method of skin observation, to a number of modern techniques that assess skin perfusion.

Color-coded duplex sonography, computed tomography, and magnetic resonance angiography, which can be used to assess digital artery perfusion, have entered routine clinical practice. However, these methods do not have the possibility for a detailed assessment of microcirculatory disorders.

Currently, a number of non-invasive or minimally invasive techniques can be used to assess cutaneous microcirculation. One of these methods is chromometry, which is based on the change in skin color. Minimally invasive - its application began in 1980 with the creation of the first chromometer, which is essentially a colorimeter.

\section{Chromometry}

Chromametry is a fast, simple and non-invasive technique that measures skin color [2]. There are three main characteristics of skin color that are taken into account during the study: the pigmentation index, the degree of pallor and brightness. The test is performed using a chromometer, which is a small hand-held apparatus that is placed on the surface that needs to be evaluated to measure the reflected light through various types of filters, after calibrated xenon flash illumination [1]. The device allows calculating the three parameters in just a few seconds. The pigmentation index is of particular interest due to the ability to take into account the variations in blood volume of the skin associated with body position. The chromometer also measures the so-called erythema index, which seems less appropriate and more variable than the pigmentation index, but which can add potentially useful information about the nature of skin inflammation associated with venous disease.

In recent years, several scientific publications have confirmed the benefits of chromometry in pa- tients with chronic venous insufficiency [2]. Other conditions in which chromametry has proven its contribution are acrocyanosis and skin inflammation characterized by erythema.

\section{THERMOMETRY AND THERMOGRAPHY}

Historically, one of the first studies to quantify the index of cutaneous blood flow was thermometry. The examination is performed using thermocouples or a thermistor attached to the skin or even non-contact by infrared thermometry. The surface temperature can be mapped by an infrared camera or by contact with one with a liquid crystal lens, which allows to assess the spatial heterogeneity of the local microcirculation [1]. The modernization of the technology has led to the use of video thermography to assess the temperature in the area of interest as an objective method for assessing microcirculation. Physiologically, the body temperature of the limbs is lower than the body temperature. The measurement of the skin temperature of the limbs is a reliable source for assessing the microcirculation, although its application is significantly limited by several features:

1) lack of discriminative ability to distinguish nutritional from thermoregulatory blood flow, which leads to erroneous conclusions in pathological conditions;

2) lack of sensitivity to variations in blood flow.

For these reasons, a number of attempts have been made in recent years to modernize the methodology by implementing software for processing data obtained from the infrared camera. However, its main application remained to assess the Raynaud phenomenon.

Topical cold exposure of the hands has been shown to inhibit the post-ischemic hyperemic response in patients but not in healthy controls. Thermography can detect these differences, but it cannot differentiate the primary from the secondary Raynaud phenomenon [3].

Image 1 illustrates the setting for performing video thermography in the context of routine clinical practice. A necessary requirement before the examination is that the patient has spent at least $15 \mathrm{~min}$ utes at room temperature. The examination can be 
performed on any part of the body, after adjusting the software and correctly positioning the patient. Outerwear and accessories must be removed. The area of interest should not be in contact with other objects. After taking the pictures, the software of the device places markers (on each finger) on the hands or the corresponding limb in order to refine the examination (Fig. 3 and Fig. 4) and accurately estimate the body temperature at each point. The mean difference between the affected and contralateral limb is calculated using the points defined by the matrix.

The image in patients with Raynaud's or Algodystrophy (Complex Regional Pain Syndrome) shows significant differences in the skin temperature of the involved limb $[4,5]$. In recent years, also several reports on a successful administration of thermography as minimally invasive method for screening for tumors in the breast area were published [6].

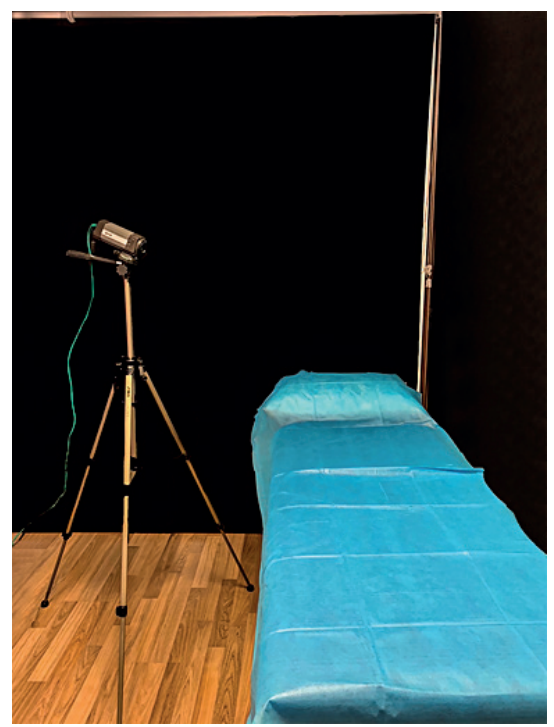

Fig. 1. Infrared camera for thermography

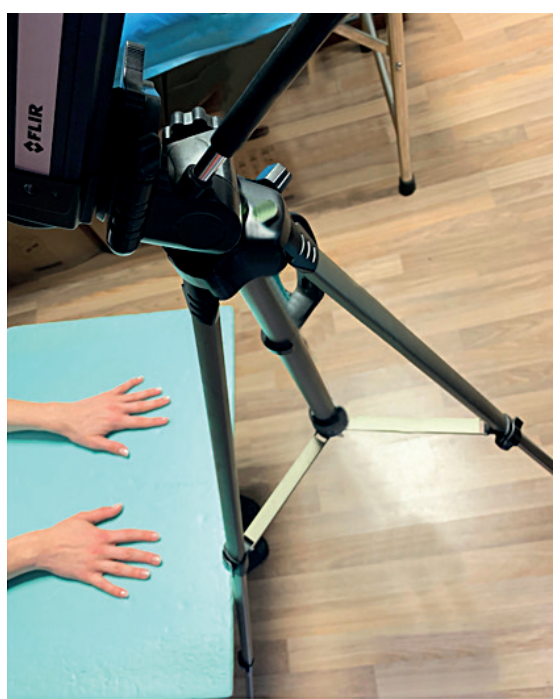

Fig. 2. Thermography in a patient with Raynaud's phenomenon

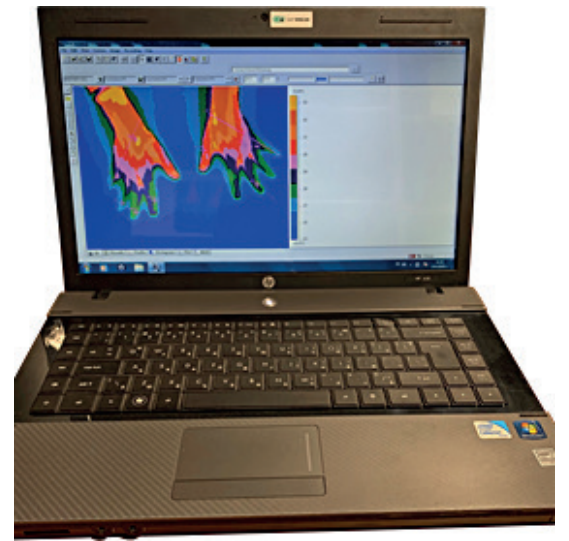

Fig. 3. Software processing of the obtained image

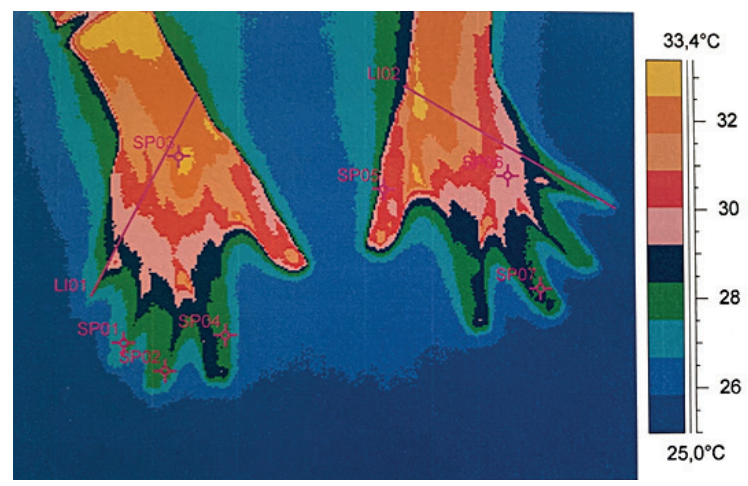

Fig. 4. Thermography of a patient diagnosed with Raynaud's phenomenon

\section{VOLUMETRY}

The measurement of the volume of the upper and lower limbs is usually performed in order to assess the swelling of the limb [7]. The value of these studies was discussed in depth in the consensus published by Vaux de Cernay and co-authors in 1997 and later supported by the Servier Research Group. The measurement of the volume of the foot is most often done by measuring the volume of displaced water - the limb is introduced into a calibrated vessel filled with warm water and the overflow of water is measured with precision. Although the methodology is simple at first glance, the reliability of the measurement depends on the accuracy, with which the physician and the patient perform it.

\section{Plethysmography}

\section{Occlusive Plethysmography}

Venous occlusive plethysmography is one of the methods for measuring blood flow, the application of which was described 110 years ago by Hewlett \& van Zwaluwenburg [8]. The study evaluates the tissue microcirculation of the entire upper or lower 
limb by measuring the increase in volume during a short period of venous occlusion caused by inflating a low-pressure cuff around the proximal limb. The basic principle of occlusive plethysmography is simple: when the venous drainage from the upper limb is interrupted for a short time, the arterial flow is unchanged and the blood can enter the forearm, but cannot be removed. This results in a linear increase in forearm volume over time, which is proportional to arterial blood flow, until venous pressure rises to the level of occlusive pressure [9]. Changes in forearm volume are measured with a plethysmograph. Initially, air and water-filled jackets were used, but they were later replaced by silastic mercury strain gauges [10]. With the development of technology, these sensors have been replaced by Indo-gallium manometers due to concerns about the potential toxicity of mercury. The strain gauges should be located around the widest part of the forearm and act as resistors connected as one arm on the Wheatstone bridge [11]. Changes in the volume of the forearm lead to a corresponding change in the circumference of the arm and, respectively, in the length of the strain gauge, which can be established as a change in the electrical resistance of the manometer and a potential difference [9]. If the change in the length of the strain gauge becomes equal to the circumference of the limb at rest, then the changes in the volume of the limb are directly proportional to the changes in resistance [12].

Venous occlusive plethysmography is widely used to study the physiology of human vessels in vivo and is most indicative when combined with intra-arterial drug administration, usually in the forearm. This methodology has become one of the „gold standards" in the assessment of vascular function in health and disease and an accurate, reproducible and convenient method to assess the effect of new vasoactive drugs.

\section{Photoplethysmography}

Photoplethysmography is a simple and inexpensive optical technique that can be used to detect changes in blood volume and in particular to assess microcirculation. Due to the non-invasive nature of the method, it is often used to perform measurements on the skin surface. The waveform of photoplethysmography includes a pulsating (,AC') physiological waveform that records cardiac synchronous changes in blood volume with each heartbeat, which is superimposed on a slowly varying (,DC') baseline with various low-frequency components reading respiration, sympathetic nervous system activity and thermoregulation [13]. The technique uses the wavelength in the red zone or near the infrared, and only a few optoelectronic components are needed: a light source to illuminate the tissue (skin) and a photodetector to detect small variations in light intensity associated with changes in perfusion. Modern photoplethysmography is based on semiconductor technology with LED and matching photodetector devices operating in the area of the red and/or nearby infrared waves $(0.8-1 \mu \mathrm{m})$. The photodetector converts light energy, which is reflected into an electric current [1]. Photoplethysmography technology is used in a wide range of commercially available medical devices to measure oxygen saturation (pulse oximeters), blood pressure and cardiac output, assess autonomic function and also detect peripheral vascular disease.

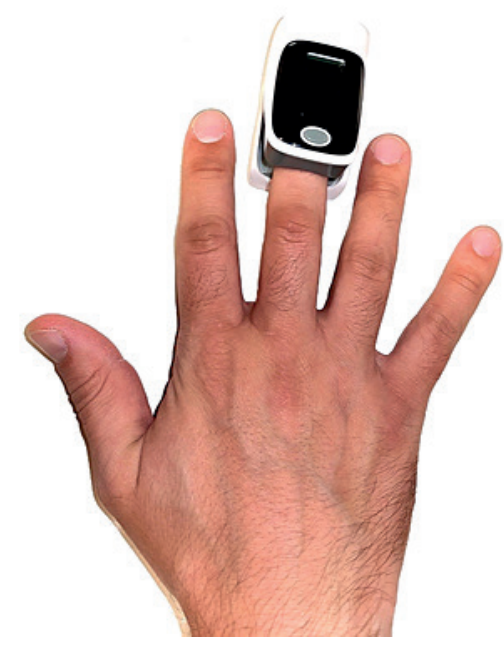

Fig. 5. Pulse oximetry (photoplethysmography)

\section{DOPPLER LASER FLOWMETRY AND LASER DOPPLER PERFUSION IMAGE}

Laser Doppler flowmetry is a modern, non-invasive method for evaluating microcirculation based on the Doppler effect created by the movement of erythrocytes through surface micro vessels when they reflect a laser light beam. It undergoes a change in wavelength (Doppler shift), depending on the number and speed of blood cells in the studied bloodstream, but not on their direction of movement [14]. In addition to a laser-generated monochrome light beam, a fiber optic transducer and sensitive photodetectors are required. The method performs a one-step study, in which the scattered laser beam is perceived by the detectors with the help of optical fibers, after which the received signals are analyzed and as a result perfusion data are obtained (Fig. 6). 


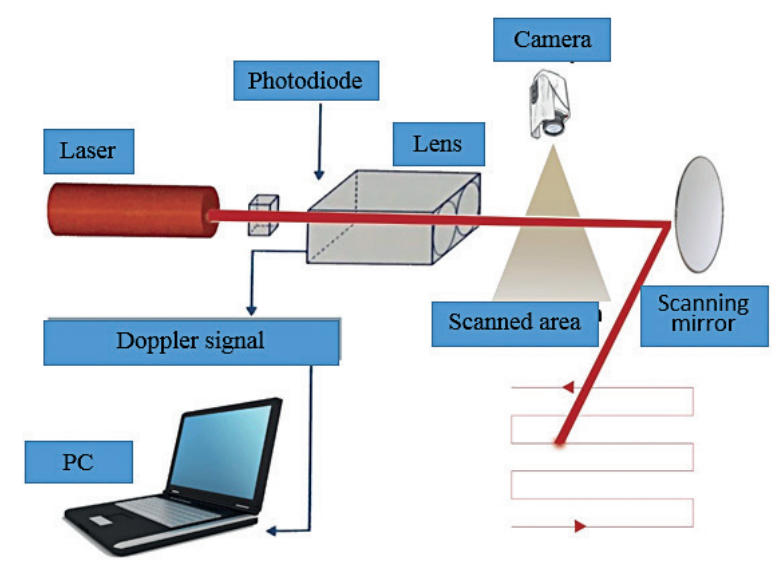

Fig. 6. Examination of microcirculation by laser Doppler flowmetry

The principle of laser Doppler flowmetry is similar to the ultrasound Doppler effect used to evaluate large vessels. The main difference is due to the speed of microcirculation in the capillaries and venules, which is in the range of 100 to $500 \mu \mathrm{m}$ and is too low to be detected by ultrasound. For this reason, coherent photons produced by low-power He$\mathrm{Ne}$ lasers are used in laser Doppler flowmetry. The depth of measurement and the volume of the measured microcirculation depend on the wavelength and the optical fibers used. With normal skin thickness and standard laser configuration, the depth of which the measurement can be performed is $0.5-1$ $\mathrm{mm}$, and the measurement volume is $1 \mathrm{~mm}^{3}$ (Fig. 7). Under these conditions, since the absorption of oxidized and deoxygenated hemoglobin is almost the same at this wavelength, any dependence on oxygen saturation is eliminated [1]. It is appropriate to perform the test at room temperature. Due to some physiological variations in peripheral perfusion, it is recommended that the skin temperature of the limbs be in the range of $32-33^{\circ} \mathrm{C}$.

In recent years, technical progress has led to many improvements and refinement of the study. The introduction of software for data processing and analysis improves and refines the results. Dual frequency sensors and multifiber probes provide simultaneous measurement of skin perfusion at two different depths.

A laser Doppler perfusion apparatus capable of capturing the signal at various points in a predetermined area has been developed. The laser Doppler viewer provides a false color perfusion map that is similar to the technique used in thermography to measure temperature (laser Doppler perfusion image).

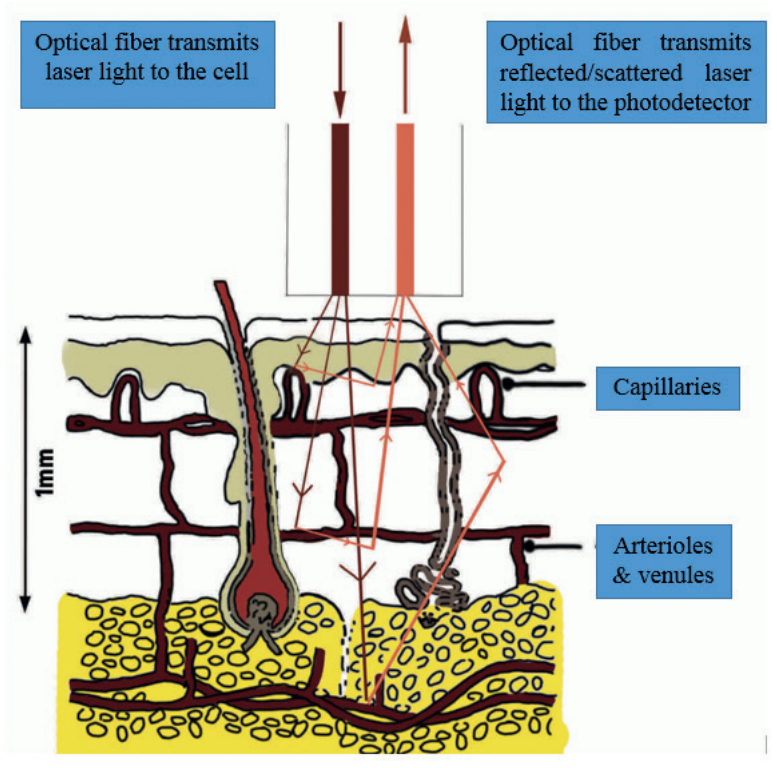

Fig. 7. Principle of laser Doppler flowmetry

Laser Doppler perfusion imaging (LDPI) is a specific test using laser Doppler flowmetry, which evaluates the perfusion in a certain area. Currently, this is performed by scanning beam and point-to-point perfusion measurements, which result in images of a few minutes. Measurements are non-contact and can register chronic changes or be performed repeatedly.

Perfusion at each image position was recorded at resolutions of 0.2 and $2.0 \mathrm{~mm}$ for further analysis. LDPI provides two-dimensional horizontal scanning of the flow in a specific tissue without the need for surface contact via a $633 \mathrm{~nm}$ low-energy laser beam [1]. The recorded Doppler signal is transmitted to a computer via an optical isolation box, demodulated and converted into an electrical signal. The perfusion signals are combined to form a color-coded image using a scale ranging from dark blue (lowest value) to red (highest value) [1].

LDPI is used to detect Raynaud's secondary phenomenon in order to distinguish whether reduced blood flow is due to systemic autoimmune disease [15]. The method is also used to assess peripheral vascular damage in vibration disease - hand-shoulder syndrome.

Recent technical developments have led to laser Doppler spectroscopic contrast imaging, which is a newly available method for examining superficial cutaneous blood flow. It uses scattered laser light to create a dot-like pattern on the skin, which has the advantage of creating a complete image [1. 16].

\section{CAPILlaRoscopy}

Capillaroscopy is a safe, easily accessible and fast diagnostic method for detecting changes 
in microcirculation [17]. It is an in vivo technique that allows the study of microcirculation using an optical magnification instrument [18]. Although it can be performed at any of the anatomical sites where the terminal capillaries are oriented parallel to the skin (eye conjunctiva, periareolar area and labial mucosa), the capillaries of the nail fold of the hands are those that are routinely researched due to their accessibility (for this reason, this technique is called capillaroscopy of the nail fold) $[18,19]$.

Capillarosopy should be performed in a room with a normal room temperature between $20-22^{\circ} \mathrm{C}$. The patient should be at rest for at least 15 minutes without being exposed to extreme temperatures to avoid vasospasm due to cold. In the absence of a stay at room temperature, it is possible to establish data on spastic capillaries and slow blood flow. Procedures such as manicures should be avoided between 15 and 30 days before the test, as cuticular trauma can generate bleeding as well as traumatize and alter the normal position of the capillaries $[20,21]$.

The most important indications for capillaroscopy include the differential diagnosis of primary and secondary Raynaud's phenomenon, as well as the assessment of changes in microcirculation by type of scleroderma. In systemic sclerosis, capillary abnormalities appear and develop in a clearly defined sequence called the scleroderma type, which correlates with the presence of changes in the internal organs as well $[22,23]$. Capillaroscopic changes are one of the classification criteria for systemic sclerosis recognized by the European League Against Rheumatism (EULAR) [24].

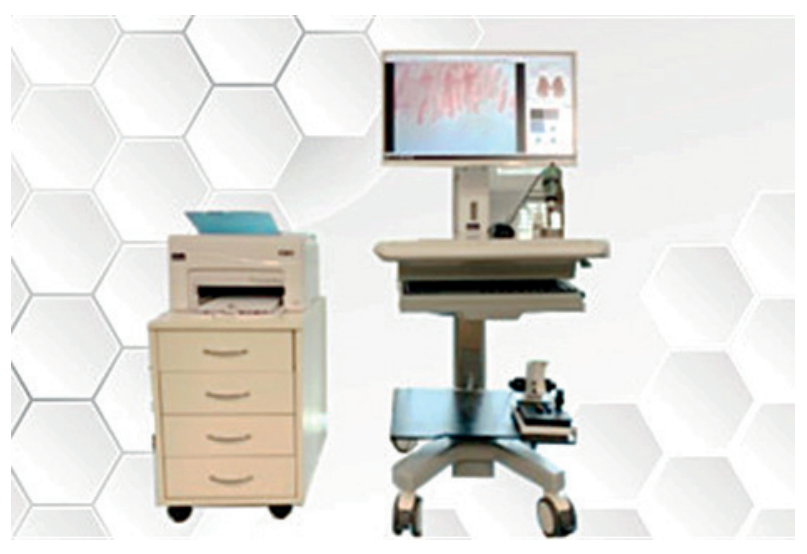

Fig. 8. Video capillaroscopy

Up to this date, many non-invasive and minimally invasive methods for assessing microcirculation have been described, which over the years have had different contributions to the diagnostic process $[25,26,27]$. With the development of technology, techniques such as laser Doppler flowmetry (and its modernized variations), as well as capillaroscopy and videocapillaroscopy have come to the fore, they have found a place both in everyday practice and in numerous clinical trials.

\section{Библиотека / References}

1. Imber B, Carpenter P. Techniques for evaluating the microcirculation. Atlas of capillaroscopy in rheumatic diseases.2017; 17-24.

2. Carpentier PH, Satger B, Poensin D, Carpentier LF. Chromametry, a promising technique for the quantification of skin changes in chronic venous disorders. 2013 Journal des Maladies Vasculaires 38(4)

3. Murray AK, Moore TL, Manning JB et al. Noninvasive imaging techniques in the assessment of scleroderma spectrum disorders. Arthritis Rheum 2009; 61; 103-111.

4. Niehof S, Huygen F, van der Weerd R et al. Thermography imaging during static and controlled thermoregulation in complex regional pain syndrome type 1: diagnostic value and involvement of the central sympathetic system. Biomed Eng Online. 2006; 5: 30.

5. Huygen F, Niehof S, Klein J, Zijlstra F. Computer-assisted skin videothermography is a highly sensitive quality tool in the diagnosis and monitoring of complex regional pain syndrome type I. Eur J Appl Physiol 2004; 91; 516-524.

6. Ng E. Y.-K. A review of thermography as promising non-invasive detection modality for breast cancer. International Journal of Thermal science. 2009;48.5. 849-859.

7. Perrin M, Guex J. Edema and leg volume: methods of assessment. Angiology. 2000; 51(1):9-12.

8. 8. Hewlett AW, van Zwaluwenburg JG. The rate of blood flow in the arm. Heart.1909;1:631-646.

9. Greenfield ADM, Whitney RJ, Mowbray JF. Methods for the investigation of peripheral blood flow. $\mathrm{Br}$ Med Bull. 1963;19:101-109.

10. Ensink FBM, Hellige G. History and principle of strain-gauge plethysmography. In: Jageneau AHM, editor. Non-invasive methods on cardiovascular haemodynamics. Amsterdam: Elsevier/North Holland; 1981. pp. 169-183.

11. Whitney RJ. The measurement of volume changes in human limbs. J Physiol. 1953;121:1-27.

12. Hokanson DE, Sumner DS, Strandness DE. An electrically calibrated plethysmograph for direct measurement of limb blood flow. IEEE Trans Biomed Eng. 2000;22:21-25.

13. Allen J. Photoplethysmography and its application in clinical physiological measurement. Physiol Meas. 2007 Mar;28(3):R1-39.

14. Oberg PA. Blood flow measurements. Linkoping University: CRC press, 1999.

15. Szabo N, Csiki Z, Szanto A et al. Functional and morphological evaluation of hand microcirculation with nailfold capillaroscopy and laser Doppler imaging in Raynaud's and Sjogren syndrome and polydermatomyositis. Scand J Rheumatol 2008; 37; 23-9.

16. Briers JD. Laser Doppler, speckle and related techniques for blood perfusion mapping and imaging. Physiol. Meas 2001;22;R35-66. 
17. Smith V, Cutolo M. When and how to perform capillaroscopy. Atlas of capillaroscopy in rheumatic diseases. 2017. Elsevier Srl Milano. 33-41.

18. Restrepo JP, Gutiérrez M, R. Angelis de et al. Utilidad de la videocapilaroscopia de lecho ungular en el diagnóstico de enfermedades reumáticas. Rev Asoc Colomb Dermatol, 2009;17, 154-161.

19. Lin K-M, Cheng T-T, Chen C-J. Clinical applications of nailfold capillaroscopy in different rheumatic diseases. J Intern Med Taiwan, 2009;20,238-247.

20. Cutolo M, Sulli A, Smith V. How to perform and interpret capillaroscopy. Best Pract Res Clin Rheumatol, 2013;27,237248 http://dx.doi.org/10.1016/j.berh.2013.03.001 | Medline

21. Tavakol ME, Fatemi A. Nailfold capillaroscopy in rheumatic diseases: which parameters should be evaluated?. Biomed Res Int, 2015;974530.

22. http://dx.doi.org/10.1155/2015/974530 | Medline

23. Cutolo M. Capillaroscopy links to clinical pathological issues in systemic sclerosis. In: Cutolo M, editor. Atlas of

Постъпил за печат: 26.04.2021 2.

$\triangle$ Адрес за кореспонденция:

Д-р Вл. Бояджиева, дм

Клиника по ревматология

УМБАЛ "Св. Ив. Рилски"

Медицински университет

бул. „Акад. Иван Гешов“ 15

1606 София

e-mail: vladimira.boyadzhieva@gmail.com
Capillaroscopy in Rheumatic Diseases. Milan: Elsevier; 2010. 173-179

24. Cutolo M, Sulli A, Pizzorni C, et al. Nailfold videocapillaroscopy assessment of microvascular damage in systemic sclerosis. J Rheumatol. 2000;27:155160.

25. Van den Hoogen F, Khanna D, Fransen J. 2013 classification criteria for systemic sclerosis: an American College of Rheumatology/European League against Rheumatism collaborative initiative. Arthritis Rheum. 2013;65:2737-2747.

26. Chia PY, Teo A and Yeo TW. Overview of the Assessment of Endothelial Function in Humans. Front. Med. 2020;7:542567. doi: 10.3389/fmed.2020.542567.

27. Abularrage C, Sidawy A, Aidinian G et al. Evaluation of microcirculation in vascular disease. Journal of vascular surgery. 2005;42;3; 574-581.

28. Yasuda K, Miyatake T, Murashita T, Sakuma M. Physiological diagnostic techniques of patients with vasculitis. 1994;52(8):2060-5.

Submitted: 26.04 .2021

$\triangle$ Correspondence address:

VI. Boyadzhieva, MD, PhD

Clinic of Rheumatology

UMHAT Sv. Ivan Rilski

Medical University

15 "Acad. Ivan Geshov" blvd.

1606 Sofia

e-mail: vladimira.boyadzhieva@gmail.com 